\title{
Interlanguage and 20th Century Scientific Communication
}

\author{
Frank Esterhill \\ Interlingua Institute
}

\begin{abstract}
A bstract
At theoutsetofthe20thcentury, itwastakenforgranted thatthetrue test of any auxiliary language would be its adoption for use in the sciences. Interlingua, the product of the International Auxiliary Language Association [IALA], founded in 1924, emerged from the increasingly naturalistic linguistic models of the late 19th and early 20th centuries (especially those of Liptay, Lott, and Peano), acknowledging the fact thatitwasthesurvivingelements of the Latin language that had lent to the modern tongues of the European littoral their character of internationality and consequently distancing itself from the complicated schematism of Volapu焱 Esperanto, and their many imitators. For a relatively long period of time, a quarter of a century, the Interlingua of IALA seemed to meet the expectations of its builders that it would function as a vehicle of scientific communication:morethantwodozenmedicaljournalsprinted abstracts in Interlingua and eleven world medical congresses issued summaries in Interlingua. Then, suddenly, atthestart of the 1980sscientific work in Interlingua came to an abrupt end (translations in the Multilingual
\end{abstract}


Compendium of Plant Diseases for the U.S. Department of Agriculture and abstracts in the New York State Journal of Medicine being the final scientific projects) from which there has been no recovery.

\section{Introduction}

Universal language became a fashionable subject only with the decline of Latin as the common idiom of the sciences in the $17^{\text {th }}$ century. In England alone, Francis Lodwick, Cave Beck, George Dalgarno, and, especially, Bishop John Wilkins published their universalist schemes in a period which lasted slightly over twenty years, but the subject fell out of favor almost immediately and the projects languished in benign neglect for more than a century. Then in the second half of the 19th century several "international" languages were invented by a series of amateurs (Pirro, Sudre, Schleyer, Zamenhof, Sotos-Ochando, Lauda, Liptay, Lott, Peano and a multitude of others), each attracting its own often exquisitely small but devoted coterie of followers. An impartial student of the subject can easily trace in the evolution of these a posteriori systems the ontogenesis of a new Latinity (Ruhrig 1980:2-3), culminating in the $20^{\text {th }}$ century in the registration of the international vocabulary by the International Auxiliary Language Association [IALA] under the direction of E. Clark Stillman and Alexander Gode in the Interlingua-English Dictionary (1951).

\subsection{Preliminary Organizational Steps}

At the start of the 20th century, Louis Couturat, professor of philosophy (and successor to Henri Bergson) at the Collège de France, brought renewed intellectual respectability to the topic with the discovery of unpublished manuscripts of Leibniz (1901, 1903a), discussing, inter alia, Descartes on the subject.' Couturat's later 
historical studies $(1903 \mathrm{~b}, 1907)$ helped to popularize the subject by bringing it to the attention of a much wider audience. Along with his colleague, Léopold Leau, he spearheaded the Délégation pour l'adoption d'une langue auxiliaire internationelle (the former as treasurer, the latter assecretary general), whose small Comité, instead of recommending an extant project, proposed as a reform candidate its own language, Ido, in 1908. The proponents of Ido recognized from the start that the ultimate test of any "constructed" language would be its usefulness for scientific communication, yet such success always eluded them.

\subsection{Foundation of the International Auxiliary Language Association}

As early as 1902, the Nobel Laureate, Wilhelm Ostwald, at the University of Leipzig, had interested his student, the young chemist, Dr. Frederick Gardner Cottrell, in the idea of an auxiliary language. After the First World War, Cottrell, Chairman of the Committee on International Auxiliary Language (from 1919 to 1936) of the International Research Council, persuaded two wealthy and prominent New Yorkers, Alice Vanderbilt Morris and Dave Hennen Morris, to found the International Auxiliary Language Association [IALA] in 1924, with an illustrious team of prominent academics and business leaders. ${ }^{2}$ Replacing the dilettantism which had preceded it with a new professionalism, IALA, for a dozen years, sponsored linguistic research (under the aegis of Edward Sapir, Otto Jespersen, and William E. Collinson, together with Albert Debrunner, Edgar von Wahl, Giuseppe Peano, Joseph Vendryes, and others) and organized meetings dedicated to the task of effecting conciliation between the already existing

\footnotetext{
${ }^{1}$ Descartes in his letter to Marin Mersenne, November 20, 1629, was responding to a placard in Latin with six propositions.

2 Alice Vanderbilt Morris remained IALA's Honorary Secretary (and its sustaining force) until her death on August 15, 1950.
} 
auxiliary language systems (Falk 1999:40-58, Esterhill 2000:1-9).

Then, in 1937, realizing that all of the previously elaborated interlanguages were fundamentally flawed and that compromise was impossible, IALA abandoned all hope for the existing auxiliaries and embarked upon its own independent work. Even in the preliminary documents--Cottrell's Report of Progress (1923) and IALA's Outline of Program from the following year--IALA, although suggesting that it could proceed by modifying an existing interlanguage, had already signalled that a different approach might be necessary when it resolved to seek a solution to the problem either"bytheadoption of one of the existing synthetic languages, as for example Esperanto, Ido, or modern Latin, or by the creation of a new language based in so far as may be found desirable upon these (Cottrell 1923:14)...." In its Outline of Program (1924), IALA somewhat confusingly asserted that "[t]he Association has no intention of developing or promoting any new language (1924:13)..." after it had already been stated, echoing the words of Cottrell's report from the previous year, that "[t]he IALA therefore stands for the adoption or modification of a synthetic or classical language, or the creation of a new language (1924:6)..." In fact, IALA did not initially undertake any independent work to formulate a new language but instead devoted its entire first decade to the hopeless task of attempting to effect reconciliation among the rival auxiliaries then in existence. Strangely, the pre-eminent linguists within IALA failed to provide much constructive guidance over the years. Edward Sapir, enthusiastic about the subject from the start (1925), while remaining affiliated with IALA for most of the 1930s, serving a brief stint as Director of Research from September, 1930 to the end

\footnotetext{
${ }^{3}$ The Memorial (in Cottrell's report) was revised the following year to state that an auxiliary language should be established by the adoption or modification of a synthetic or a classicallanguage orbythecreationofanewlanguage(Cottrell1923; revised 1924).

${ }^{4}$ This was IALA's intent until 1936. Cf. A Plan for Obtaining Agreement on an Auxiliary World-Language (1936).
} 
of July, 1931 and authoring monographs (1930, 1932) whose publication was in part funded by IALA, seems to have played no pivotal role in that organization (Esterhill 2000:7, note 6). Otto Jespersen, author of Novial, although vocal in his criticism of Esperanto in his correspondence from Denmark, did not actively champion his own creation. He remained, until his death in 1943, peripheral to IALA which had always been headquartered in New York. Finally, William E. Collinson (IALA's Director of the Technical Staff at the University of Liverpool), a strident Esperantist who had provoked much criticism, was quietly swept aside, and control over IALA's work was transferred into the hands of his competent assistant, E. Clark Stillman, when the dictionary work was begun.

With a grant from Rockefeller Foundation in January 1937, IALA began the second (and final) stage of its research, the registration of the international vocabulary, under Stillman at the University of Liverpool. Stillman had already elaborated the three-year program of research and experimentation which would eventuate in the grammar and nuclear vocabulary of the language which IALA would recommend. HewasnamedSecretary of the Committee for Agreement in the following year (1938) and the Technical Staff at Liverpool was placed "under his immediate direction (International Auxiliary Language Association 1939:8)."

It was originally anticipated that the entire project would require only three years to complete the determination of IALA's language and to ready its core:

This core will consist of a Grammar and a Vocabulary of about 2000 of the most frequent root-words required for ordinary usage, together with nuclei of a number of vocabularies in certain specialist fields. Throughout the period, a staff of linguistic workers, expert in both ethnic and constructed languages, will be working at Liverpool University under the immediate direction of the Assistant Director of Technical 
Research, Mr. E. Clark Stillman (International Auxiliary Language Association 1939:10).

\subsection{Formulation of the Interlanguage}

Upon the outbreak of war in Europe in 1939, IALA's files and records were safely transferred to New York where Stillman assembled a new team to continue the work. He enlisted the support of an able assistant, Alexander Gode, who assumed the direction of IALA when Stillman resigned in March, 1943 in order to go on war duty. IALA at that point had firmly committed to the International Vocabulary ${ }^{6}$ but wasstill debating the question as to whether it should be schematized, and, if so, to what extent.

Gode (1942), summing up the status of IALA's work to that point, wrote (Roman numerals in square brackets referring to the numbered

\footnotetext{
${ }^{5}$ Collinson, in name at least, remained Director of the Technical Staff at Liverpool, but since he was not perceived as an impartial, non-sectarian, or neutral party, he appears to have provoked severe criticism. At the March 21, 1939 meeting of the Committee for Agreement, he finally asked that in his future collaboration in the work of CA [Committee for Agreement] he might be exempted from all linguistic work other than purely objective studies. In 1941, Collinson was promoted up to Director oftheResearchStaff (part-time, onwarleave), eventhough the war had, from 1939 on, severed most connections between him and IALA. He retained his title(andhissalary)untilhisspecial arrangementwithIALA was terminated in 1942. Years later he confessed to an American Esperantist, Ivy Kellerman Reed (1958:1388), that he had beenunaware of IALA's dictionary work which had been begun at Liverpool.

${ }^{6}$ In his Remarks on the Basic Formula for an IL Vocabulary, a paper prepared for Collaboration MeetingNo.1,June 24,1940,Stillmanhaddefinedthe formula thus: All words common to most of the Romanic languages and English have the right to existintheIL.... Withthisformulawehavethemostinternationalcriterionwhich is consistent withobtaining an adequate vocabulary. It is difficult to see how any other basis of selection could be found which wouldnotbeatoncemorearbitrary and less international in its results...and we are therefore left with that criterion as thesoundest basis for an IL: Allwords common tomostoftheRomaniclanguages and English have a claim to existence in the IL.
} 
paragraphs of Gode's report) that "[II.][t]he focus of all of IALA's enterprises is the compilation of the International Vocabulary." The only reason why no agency before IALA had attempted to undertake the task "[III.] ... must be seen in the fact that it is extremely difficult to establish objective criteria of inclusiveness for this vocabulary.... To have solved this seemingly insoluble problem is one of IALA's indisputable claims to scientific honors." That the Romance languages, the descendants of classical Latin, must be taken into consideration by any auxiliary was axiomatic; IALA innovated in stipulating that English, a Germanic tongue which had been heavily infiltrated by Latinate idioms over the course of centuries, must be included in this group. This approach, according to Gode, provided an objective criterion for the elaboration of the prototypes of the International Vocabulary?: "[XI.] By defining Internationality of word material means internationality within the Anglo-Romance group of languages' IALA solved the problem of an objective criterion of internationality and also of a method usable to determine its comparative degree." The four provenance languages for the vocabulary therefore were Italian, French, Spanish/Portuguese, and English. The major concern was lexical:

"[LXXVII.] It is the contention of the naturalistic school of thought that the major problem of interlinguistics is that of vocabulary deduction. This problem can be considered as solved when principles have been establishedwhich permit the objective elaboration of an immediately available adequate international auxiliary vocabulary and whose objective potency can never be exhausted so that they (the principles) will always be available to supply new formations of absolutely certain identity for new

\footnotetext{
${ }^{7}$ IALA had devised a method [XVI.] that permitted the summingupofthenational variations of an international word in a symbolic form called the "international prototype". The prototypes could also be described in a negative way: [LIII.] the International Vocabulary develops from the national vocabularies by a process of suppression or neglect of all individual-language idiosyncrasies.
} 
needs as these arise, i.e., formations not depending on the decision of an academy or other legislative body but simply yielded by the application of the rules and principles themselves. The naturalists contend that their principles andrulesanswerthis description in fairly full measure.

[LXXVIII.] Compared with the problem of vocabulary deduction, problems of grammar, the naturalists contend, are of minor or at least secondary importance."

At that time IALA was divided into two schools of thought (the "schematic" and the "naturalistic") concerning the language which it would propose. On the one hand, Alice V. Morris, William E. Collinson, and, to a lesser extent,Wayne J.Kostir,wished to introduce schematization into the auxiliary language, whereas Stillman opposed such a move. On one fundamental point, however, all were agreed--that the international vocabulary upon which an auxiliary would be based must be elaborated in a scientific and objective manner:

[XXVII.] The International Vocabulary stands as a solid rock fit to support all sorts of superstructures. Workers engaged in the elaboration of auxiliary language projects must look upon the International Vocabulary as natural raw-material, as something factual and God-given from which they can derive, on which they can erect, out of which they can make all sorts of things but over whose being and becoming they have no jurisdiction.

The next month, Stillman (1942:3), in a Memorandum on Gode's Report, confirmed the "accuracy and importance" of the statement that the international vocabulary was IALA's primary concern. This distinction between the international vocabulary and any language built out of it was later underlined by Gode and Blair when they noted in the preface to the Interlingua Grammar (1951b) that it was "a grammar of the international language" (original emphasis). 
By the time World War II was over, IALA had completed its basic work and was ready to offer to the public, in its General Report 1945, three (the naturalistic and two schematic) variants of its proposed interlanguage, grounded in the solid foundation of the international vocabulary. In 1946, André Martinet joined IALA's staff briefly, formulating an analysis ofIALA's(now) four variants (1947a),with two naturalistic models: modern and classic. The four variants (P, M, C, and K) fell, according to the Présentation des Variantes (IALA 1947b), into two classes: (a) those which stressed conformity to the etymological prototype of each word and (b) those which permitted schematization or regularization of pronunciation, spelling, or derivation. Within the naturalistic tradition, the variant $\mathrm{P}$ (presumably for "Peano") presented international prototypes in a classic form, whereas the variant $\mathrm{M}$ presented the same basic vocabulary in a more modern form ("sous une forme obtenue en suivant les directives de la majorité des langues intéressées"). In the schematic versions (C, which was modelled on Occidental, and $\mathrm{K}$, which was modelled on Novial), the international vocabulary has been subjected to a process of regularization. The only distinguishing feature between the last two variants is the fact that the rules for regularization are simpler and fewer in variant $\mathrm{K}$ than in variant C.VariantCsoughttocombineboth regularity and naturalism. It retained an orthography (whence, presumably, "C") that was less regular than that of the more highly schematized variant $\mathrm{K}$ (and, hence, more in accord with established European norms). The "regula de Wahl" affecting supine stems, moreover, introduced an additional degree of complexity into variant $\mathrm{C}$.

Martinet and Vinay had prepared a questionnaire (1946) which was sent to respondents in several nations. The result of that poll was a solid rejection of schematism. ${ }^{8}$ After Martinet's abrupt departure in

\footnotetext{
${ }^{8}$ Martinet (1949:590-591) later remarked at the Sixth International Congress of

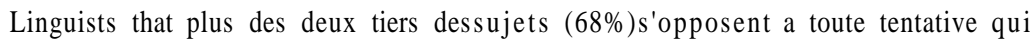
aurait pour résultat de modifier la structure même des mots internationaux.
} 
1948 in a dispute over salary (Esterhill 2000:15, note 17), Alexander Gode once again assumed the direction of IALA's staff and brought the work to completion, on the modern and naturalistic models, with the publication of the Interlingua-English Dictionary and the Interlingua Grammar in 1951, using the legacy which had been left to IALA by Alice V. Morris for that purpose (Falk 1999:81).

\section{Scientific Use of Interlingua}

\subsection{Application in the Sciences}

The application of Interlingua to the sciences began the next year with Dr. Forrest F. Cleveland's Spectroscopia Molecular, and it advanced further in 1953 with the inception of Scientia International, published by the Interlingua Division of Science Service. IALA was eventually disbanded in the 1950s when its funding was exhausted, but over the span of approximately twenty-five years, Interlingua summaries appeared in more than two dozen medical journals (including American Heart Journal, American Journal of Clinical Pathology, American Journal of the Medical Sciences, Annals of Internal Medicine, Archives of Interamerican Rheumatology, Archivos Peruanos de Patologia y Clinica, Arthritis and Rheumatism, Blood: the Journal of Hematology, The Bridge, Circulation:Official Journal of the American Heart Association, Circulation Research: Official Journal of the American Heart Association, Clinical Orthopaedics, Danish Medical Bulletin, Diabetes, Haematologica Polonica, Hawaii Medical Journal, Journal of the American Medical Association, Journal of Dental Medicine, Journal of Dental Research, Journal of Pediatric Surgery, Pediatrics, Radiology, Revista Cubana de Cardiologia, Quarterly Bulletin of Sea View Hospital, Technical Bulletin of the Registry of Medical Technologists, and West Indian Medical Journal). Gode usually furnished the translations, but the summaries in the 
prestigious Journal of the American Medical Association were prepared by its own staff. In addition, Gode supplied Interlingua abstracts totalling thousands of pages for eleven world medical congresses between 1954 and 1962 (Second World Congress of Cardiology [Washington 1954], Thirteenth M \& R Pediatric Research Conference [Syracuse 1954], First International Symposium on Venereal Disease and the Treponematoses [Washington 1956], Sixth Congress of the International Society of Blood Transfusion and the Ninth Annual Meeting of the American Association of Blood Banks [Boston 1956], Sixth Congress of the International Society of Hematology [Boston 1956], Ninth International Congress on Rheumatic Diseases [Toronto 1957], Eleventh International Congress of Dermatology [Stockholm 1957], Ninth International Congress of Pediatrics [Montreal 1959], First International Congress of Endocrinology [Copenhagen 1960], Third World Congress of Psychiatry [Montreal 1961], and Twelfth International Congress of Dermatology [Baltimore and Washington 1962]). In his lifetime, Alexander Gode published approximately a million words of Interlingua, but by the end of the 1960s there was very little demand for it.' The Interlingua Division of Science Service was dissolved at the end of 1966, upon the retirement of Dr. Watson Davis. In the next month, at the end of January 1967, Hugh E. Blair, Gode's assistant and co-author of the Interlingua Grammar, died unexpectedly. Ashisownheal thbegantofail,Godeundertookthetask of founding, in his few remaining years, an organization which would continue the work of IALA. Accordingly, the Certificate of Incorporation of the Interlingua Institute was filed with the Secretary of State of the State of Delaware by the three Incorporators, Henry Fischbach, Alexander Gode, and Alice Morris Sturges on March 31, 1970. When Gode died on August 10 of that year, it was for a while

\footnotetext{
${ }^{9}$ Beginning in 1967 andcontinuingin 1968 therehasbeenanunmistakableregression in thedemands forInterlinguatranslations. Ihavenoreasontopredict thatthistrend will continue, but I have noreason either to expect that there will be considerable Interlingua gains in this area (Gode 1968).
} 
uncertain whether the Interlingua Institute would long survive him.

Yet, Interlingua continued to be use for scientific purposes for another fifteen years. Abstracts in Interlingua, prepared by Eduardo I. Juliet, M.D., were printed in New York State Journal of Medicine for a decade from 1974 on, and Frank Esterhill provided Interlingua translations for the two volumes of Paul R. Miller's Multilingual Compendium of Plant Diseases (1976 and 1977). Then, in the late 1980s, Spectroscopia Molecular failed to appear after more than a quarter of a century of uninterrupted monthly publication. The final chapter in the distinguished history of Interlingua in the service of science had suddenly come to an abrupt close after more than thirty years of serious attention by the international scientific community.

\subsection{Interlingua as Vector of the International Scientific Vocabulary}

The foundations of Interlingua were laid at the end of the 1930s when IALA, under E. Clark Stillman, at long last undertook its own original work. B. C. Sexton (1979:4) correctly summed up the importance of Stillman's contribution, remarking that "[h]e saw that the work of his team should consist primarily in the extraction and the establishment of the international vocabulary, i.e., of those words whose presence in the multiplicity of the great cultural languages of the world constitute the indispensable condition of the viability of the concept of an international auxiliary language."

Shortly before his death, in defining the essence of the Interlingua of IALA, Gode (1968:4-5) stressed the non-original nature of the language, the fact that it was based upon two fundamental premises:

...(1) the existence of an "international scientific vocabulary" and (2) the close structural affinity of all the languages of western civilization. 
The "international scientific vocabulary," for which P. B. Gove (as editor of Webster's Third New International Dictionary of the English Language) introduced the lexicographical label "ISV," consists (virtually in its entirety) of words and word-building elements native to classical Greek and Latin and hence (1) historically shared by the romance and teutonic languages as keepers and beneficiaries of the cultural and linguistic Greco-Latin tradition and (2) made familiar to sophisticated speakers of all languages (including those outside the Greco-Latin orbit) through the world conquest of science and technology, which (radiating from the West) used them in the past and are still using them today as their linguistic vehicle.

Whereas earlier attempts in the field had focused mostly on a priori systems $\left(17^{\text {th }}\right.$ century), so-called "Acompromise" languages (Pirro), and deformed vocabularies of European tongues (Schleyer, Zamenhof), IALA based its Interlingua on the already-existing international vocabulary. Unlike Peano who had looked to classical Latin for inspiration,Stillman and Gode, following in the footsteps ofLiptay and Lott, recognized that any successful international language had to be based upon those elements of Latin which have survived in the modern idioms--precisely those elements which have lent to the modern languages their character of internationality.

\subsection{Failure of Esperanto and Ido to Win Acceptance in Scientific Communication}

IALA, at its founding, had perceived the need for an auxiliary language, especially in the sciences:"The publication of scientific articles and abstracts in a constantly increasing number of mother-tongues together with the wide-spread distribution of the same has intensified the scientist's need for a common linguistic medium. That which Descartes considered an advantage several centuries ago 
has now become an urgent necessity (1924:5)." It was not surprising that Interlingua made such impressive initial progress in the field of science and it should not have been unforeseen that earlier auxiliary languages which had mangled the international scientific vocabulary in order to make it fit their narrow grammatical criteria would enjoy so little success. As B.C.Sexton (2001:9) has observed, "It has been said that science is the only branch of learning that is truly international, yet none of the previous international auxiliary languages made any headway in this field, not even Ido in spite of the support of Ostwald, Nobel prize-winner for his work in colour science, and its brave attempt to set up an international patent review. Scientists were not likely to favour a schematic language that required the rebaptism of the entire scientific vocabulary."

Interlingua, the only interlanguage ever adopted for serious and extensive use in the sciences, survived little more than a quarter of a century. The goal of interlinguistics from the start of the twentieth century, professional recognition of the usefulness of an auxiliary language through its acceptance in the sciences, had never been reached until the publication of Interlingua, and--ironically--professional interest in the subject of interlinguistics (which had been late to emerge after centuries of deliberation) evaporated shortly thereafter.

Martinet (1952:163), in his somewhat bitter review of the Interlingua-English Dictionary, the fruition of all of IALA's labors, observed, not entirely unfairly, that the "common mistake of almost all language-makers is to assume a demand where there is practically none." Gode himself had noted (1968:8) that Interlingua could function as a "bridge language in scientific and, specifically, medical communication." Still, he had to add that the "argument that Interlingua summaries are useful is sound, but the argument that Interlingua summaries are indispensable is nonsense." Echoing Liptay, who had commented upon the rise of English in the last years of the nineteenth century, he remarked that "English owes its overriding international significance to the fact that it is (among all the languages of the 
western world) the most effective vehicle of the international scientific vocabulary...(1968:9)"

\section{Conclusion}

There was no need (and nouse) ever for the international languages of the $19^{\text {th }}$ and early $20^{\text {th }}$ century and today, with the unparalleled ascendancy of English, there is no further need for Interlingua or any other interlanguage. The languages of the European littoral have become the tongues of the New World and subsequently the idiom of the whole world, bringing the Latin vocabulary of which they are the carriers to its ultimate destination as the patrimony of the entire earth.

\section{References}

Cottrell, F. G. 1923. Report of Progress, August 1923. Washington, D.C.: International Auxiliary Language of the International Research Council.

Couturat, L. 1901. La Logique de Leibniz, D'apres des Documents Inedits. Paris: Hachette (reprinted by Hildesheim: G. Olms 1961).

Couturat, L. 1903a. Opuscules et Fragments Inedits de Leibniz, Extraits des Manuscrits de la Bibliotheque Royale de Hanovre. Paris: Hachette (reprinted Hildesheim: G. Olms 1961).

Couturat, L. 1903b. Histoire de la Langue Universelle. Paris: Hachette (reprinted by Hildesheim: G. Olms 1979).

Couturat, L. 1907. Les Nouvelles Langues Internationelles. Paris: Hachette (reprinted by Hildesheim: G. Olms 1979).

Esterhill, F. 2000. Interlingua Institute: A History. New York: Interlingua Institute.

Falk, J. S. 1994. The Women Foundation Members of the Linguistic Society of America. Language 70, 455-490.

Falk, J. S. 1995. Words without Grammar: Linguists and the International Auxiliary Language Movement in the United States. Language and 
Communication 15, 241-259.

Falk, J. S. 1999. Women, Language, and Linguistics:Three AmericanStories fromtheFirstHalf of the Twentieth Century. Routledge: London \& New York.

Gode, A. 1942. Report on the Present State of IALA's Research. Mid-October, 1942. Typescript.

Gode, A. 1951. Interlingua-English Dictionary. New York: Storm Publishers.

Gode, A. 1968. Report on Interlingua Activities in the United States during the Calendar Year of 1968. Ms., New York.

Gode, A. \& H. Blair. 1951. Interlingua Grammar. New York: Storm Publishers.

Gove,P. B. 1961. Webster's Third New International Dictionary. Springfield, Mass: G. \& C. Merriam Co.

International Auxiliary Language Association. 1924. Outline of Program. New York: International Auxiliary Language Association in the United States, Incorporated.

International Auxiliary Language Association. 1936. A Plan for Obtaining Agreement on an Auxiliary World-language. New York: International Auxiliary Language Association in the United States, Incorporated.

International Auxiliary Language Association. 1939. Annual Report for 1938. New York: International Auxiliary Language Association in the United States, Incorporated.

International Auxiliary Language Association. 1945. General Report for 1945. New York: International Auxiliary Language Association in the United States, Incorporated.

International Auxiliary Language Association. 1947a. Variantes de le Lingua Internationale. New York: International Auxiliary Language Association in the United States, Incorporated.

International Auxiliary Language Association. 1947b. Présentation des Variantes. New York: International Auxiliary Language Association in the United States, Incorporated.

Liptay, A. 1890. La Lengua Católica ó Sea Proyecto de un Idioma Internacional sin Construcción Gramatical. Paris: Roger \& Chernoviz.

Liptay, A. 1891. Eine Gemeinsprache der Kulturvölker. Leipzig: F. A. Brockhaus (reprinted by Hildesheim: G. Olms 1991).

Liptay, A. 1892. Langue Catholique: Projet d'un Idiome International sans 
Construction Grammaticale. Paris: Bouillon.

Lott, J. 1890. Un Lingua Internazional: Grammatika et Vokabular Pro Angleses, Germanes, Romanes et Pro Cultivates de Tut Mond. Leipzig: Frankenstein \& Wagner.

Martinet, A. 1949. Rapport sur L'êtat des Travaux Relatifs a la Constitution d'une Langue Internationale Auxiliaire. Actes du Sixieme Congres International des Linguistes. Pairs: Congres International des Linguistes.

Martinet, A. 1952. Review of Interlingua-English Dictionary. Word 8, 163-167.

Martinet, A. \& J. P. Vinay. 1946. Questionnaire. New York: International Auxiliary Language Association in the United States, Incorporated.

Miller, P. \& H. Pollard. 1976. Multilingual Compendium of Plant Diseases I. St. Paul, MN: American Phytopathological Society fortheUnitedStates Agency for International Development in Cooperation with the Agricultural Research Service, United States Department of Agriculture.

Miller, P. \& H. Pollard. 1977. Multilingual Compendium of Plant Diseases II. St. Paul, MN: American Phytopathological Society for the United States Agency for International Development in Cooperation with the Agricultural Research Service, United States Department of Agriculture.

Reed, I. 1958. Letter to the Editor. Science 128, 1388.

Ruhrig, H. E. 1980. Un Historia de Lingua Universal. Currero International de Interlingua 17, 2-4.

Sapir, E. 1925. Memorandum on the Problem of an International Auxiliary Language. Romanic Review 16, 244-256.

Sapir, E. 1930. Totality. InAlice V. Morris (ed.), Language Monographs 6. Baltimore: Waverly Press.

Sapir, E. \& M. Swadesh 1932. The Expression of the Ending-point Relation in English, French, and German. In Alice V. Morris (ed.), Language Monographs 10. Baltimore: Waverly Press.

Sexton, B. C. 1979. The Formation of Interlingua. Eco-logos 25, 3-5.

Sexton, B. C. 2001. Review of Esterhill 2000. Lingua e Vita 101, 9-10.

Stillman, E. C. 1940. Remarks on the Basic Formula for an IL Vocabulary. Prepared for Collaboration Meeting No. 1, Annex A, June 24, 1940. Typescript.

Stillman, E. C. 1942. Memorandum on Report on the Present StateofIALA's Research by Mr. Gode-von-Aesch. November 11, 1942. Typescript. 